worked commercially. In spite of its dryness, Death Valley is by no means barren; more than 500 kinds of plants live there and on these subsist many animal species. Some of the notable natural features are Telescope Peak, Furnace Creek, a green valley despite its name, and Ubehebe Crater.

\section{Engineering Research in Japan}

ThE National Research Council of Japan (Imperial Academy House, Ueno Park, Tokyo) publishes a series of journals or reports each of which deals with some branch of science. Of these, vol. 8 of the Japanese Journal of Engineering has recently reached us. This consists of a book of 90 pages containing abstracts of 313 papers read before various scientific and technical societies or contributed to periodicals in 1928. The abstracts are grouped under civil engineering, mechanical engineering, naval architecture, aeronautics, electrical engineering, mine engineering and metallurgy. Though the papers themselves are written in Japanese, the abstracts are in English and for the greater part have been written by the authors of the papers. In general, the subjects dealt with follow the lines of engineering research in other countries, and the volume shows that Japanese engineers have a keen appreciation of the value of original investigation.

\section{Awards of the Royal Geographical Society}

His Majesty The KIng has approved the award of the Royal medals of the Royal Geographical Society as follows: Founder's medal, to Mr. J. M. Wordie, for the work he has done in polar exploration from the voyage of the Endurance in the Weddell Sea in 1914-17 to the present day; Patron's medal, to Prof. Erich von Drygalski, for his researches in glaciology both in the arctic and the antarctic regions. The Council has awarded the Murchison grant to Dr. Noel Humphreys, for his expeditions in Ruwenzori; the Back grant to Miss Freya Stark, for her journeys in Luristan; the Cuthbert Peek grant to Dr. L. S. B. Leakey, for his studies on climatic changes in East Africa; and the Gill memorial to Khan Sahib Afraz Gul Khan, of the Survey of India, for his frontier and trans-frontier explorations and surveys.

\section{Announcements}

Mr. M. T. DAwE, director of agriculture, Cyprus, has been appointed by the Secretary of State for the Colonies to be director of agriculture and forests, Palestine.

Tue Gesellschaft Deutscher Naturforscher und Aerzte will not meet this year. The next meeting, the ninety-third, is to be in Hannover in 1934. Local secretaries are : Prof. C. Müller and Prof. Dr. Willige, both of the Technische Hochschule, Hanover.

AT the meeting of the London Mathematical Society on April 27 at 5 p.m. at Burlington House, Prof. B. L. van der Waerden, of the University of Leipzig, will deliver a lecture on "Hypercomplex Numbers". Members of other scientific societies who may be interested are invited to attend.
Arrangements are being completed for the holding of the 1933 meeting of the Canadian Phytopathological Society at Regina, Sask., in July, in conjunction with the World's Grain Fair and the C.S.T.A. Convention. A committee under the chairmanship of Dr. P. M. Simmonds, Saskatoon, has been appointed to look after local arrangements. The secretary of the Association is T. G. Major, Central Experimental Farm, Ottawa.

THE papers read at the conference on "Protein Swelling and Allied Phenomena" held at the Leathersellers Hall, E.C.2, on December 1, are being reprinted in book form, ineluding the introductory address by Prof. F. G. Donnan. The book is of about 124 pages, and copies will be shortly obtainable from the Offices of the International Society of Leather Trades Chemists at 17, Market Street, London, S.E.1 ; price 5s. 6d., including postage.

THE Quekett Microscopical Club has arranged a series of demonstrations in connexion with microscopy, which are being given on the same evenings as the ordinary fortnightly meetings for the next three months. The meetings are held in the rooms of the Medical Society of London, 11, Chandos Street, Cavendish Square, W.1. Tickets for the meetings can be obtained from Mr. Milton Offord, 8, Culmington Road, West Ealing, W.13. A brochure containing lists of recent additions to the library, cabinets and collections of instruments, of the Club has recently been published, price $1 s$. Further information regarding the Club can be obtained from the secretary, Mr. W. S. Warton, 35, Doneraile Street, S.W.6.

Applications are invited for the following appointments, on or before the dates mentioned :-An organising mistress for domestic subjects in the North Riding of Yorkshire-The Secretary, Education Offices, County Hall, Northallerton (April 25). A chief engineer and manager of the Government Electrical Undertakings, Ceylon-The Crown Agents for the Colonies, 4 Millbank, Westminster, S.W.1 (April 28). A principal of the City of Leeds Training College-The Director of Education, Education Department, Leeds (April 29). A demonstrator in the Department of Zoology at the Bedford College for Women, Regent's Park, N.W.l (April 29). A Grade 1 engineering assistant at the Mines DepartmentThe Under-Secretary for Mines, Establishment Branch, Mines Department, Cromwell House, Dean Stanley Street, S.W.1 (May 1). A probationary assistant naval constructor of the Royal Corps of Naval Constructors-The Secretary of the Admiralty (C.E. Branch), Whitehall, S.W.1 (May 1). A headmaster of the Nautical School and School of Fishermen, Boulevard--The Director of Education, Educa. tion Offices, Guildhall, Hull (May 6). A professor of education at the University of Leeds-The Registrar. A junior full-time teacher in the Department of Engineering of the Municipal Technical College, Oldham-The Director of Education, Education Offices, Oldham. An assistant instructor in the School of Navigation at University College, Southampton-The Registrar. 